\title{
Investor Attention and FX Market Volatility
}

\author{
John Goddard ${ }^{\mathrm{a}}$, Arben Kita ${ }^{\mathrm{b}}$, Qingwei Wang ${ }^{\mathrm{c}, *}$ \\ ${ }^{a}$ Bangor Business School, Hen Goleg, College Road, Bangor LL57 2DG, United Kingdom. \\ ${ }^{b}$ University of Southampton - Highfield Campus, Southampton, SO17 1BJ, United Kingdom. \\ ${ }^{c}$ Cardiff Business School, Aberconway Buidling, Colum Drive, Cardiff, CF10 3EU, United Kingdom
}

\begin{abstract}
We study the relationship between investors' active attention, measured by a Google search volume index (SVI), and the dynamics of currency prices. Investor attention is correlated with the trading activities of large FX market participants. Investor attention affects FX market volatility, after controlling for macroeconomic fundamentals. Causality is found to run mainly from attention to volatility. In addition, investor attention is related to the currency risk premium. Our results suggest that investor attention is a priced source of risk in
\end{abstract} FX markets.

Keywords: Investor Attention, FX Volatility, Option Pricing, GARCH

JEL: G12, G14

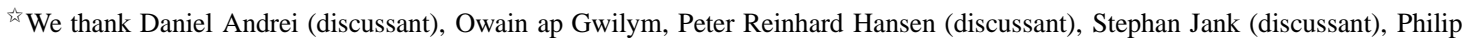
Molyneux, Alexandra Niessen-Ruenzi, Evgenia Passari (discussant), Stefan Ruenzi, Andreas Schrimpf, Elvira Sojli, and the seminar participants at Bangor Business School, ZEW Conference "The Role of Expectations in Financial Markets", the "3rd Emerging Scholars in Banking and Finance" Conference at Cass Business School in London, 2013 Swiss Finance Association (SGF) annual conference and 2014 European Central Bank workshop "Using big data for forecasting and statistics" for helpful comments. Errors and omissions remain the responsibility of the authors.

${ }^{*}$ Corresponding author. Telephone: +44 (0)29 20875514.

Email addresses: j.goddard@bangor .ac.uk (John Goddard), a.kita@soton. ac.uk (Arben Kita), wangq30@cardiff.ac.uk (Qingwei Wang)
} 


\section{Introduction}

Standard asset pricing models have difficulty in explaining some stylized empirical facts on price dynamics that are unrelated to fundamentals. These findings have motivated a growing literature, concerned with behavioral biases in trading. A literature on the implications of investor attention for the dynamics of asset prices has emerged in the last two decades. A commonly maintained assumption in traditional finance is that information acquisition is costless. In reality, the collection and processing of information requires scarce resources, such as attention, time and effort. Allocation of attention precedes portfolio allocation, and can lead to infrequent portfolio decisions, affecting aspects of the dynamics of asset prices such as stock market volatility (Andrei and Hasler, 2014), return comovement, and return predictability (Peng and Xiong, 2006).

The objective of this paper is to examine empirically the link between investor attention and the dynamics of currency prices. We test the predictions of the limited attention theory. We use a measure of search intensity through Google as an indicator of investors' information acquisition, and we examine its impact on currency prices. ${ }^{1}$ This paper contributes to a growing literature on the role of investor attention measured by online search intensity through Google, following the seminal paper by Da et al. (2011). In contrast to the previous literature that focuses on stock markets, we examine major foreign exchange (FX) markets. FX markets offer several advantages for this type of investigation. First, the marginal investor is not subject to any short-selling constraints in FX markets. Second, exchange rates are unlikely to be driven by private information. This creates an ideal environment for the investigation of information-driven trades in the absence of private information. Third, investors' acquisition of information on FX markets using Google is unlikely to be subject to accidental increment in search volume, a well-known problem for the use of search volume data based on firm ticker or firm name, both of which have multiple meanings. A search for a keyword such as "EUR/USD" is a clear indication of intent to locate a foreign exchange rate.

Even in highly liquid markets such as the FX market, information acquisition may be important for asset price dynamics. Only a small fraction of international financial holdings are actively managed (Sager and Taylor, 2006; Bacchetta and Van Wincoop, 2010). The infrequency of portfolio allocation decisions may be explained by optimal attention allocation, when information acquisition costs are added to transaction costs (Bacchetta and Van Wincoop, 2005). Rational inattention slows down the process whereby new information becomes impounded into the exchange rate, leading to predictable excess returns. Bacchetta and Van Wincoop (2005) show that rational inattention provides a solution to the forward discount puzzle. There is limited empirical evidence, however, concerning the impact of investors' information acquisition on the dynamics of currency prices, including volatility. This is partly explained by the difficulty in finding

\footnotetext{
${ }^{1}$ Since online query reflects investors' active attention to information, we refer to investor attention and information acquisition interchangeably in this paper.
} 
a suitable empirical proxy for information acquisition, a question that we address below.

Our empirical analysis begins by examining whether the search volume index (SVI) captures the demand for information in FX markets. The previous literature suggests individual investors frequently use Google to acquire information (Da et al., 2011). Conventional wisdom suggests, however, that individual investors play little role in dealer-dominated FX markets. We argue that Google search intensity is a good measure of information demand for FX investors in general, for the following reasons. First, exchange rates are unlikely to be driven by private information. Google search intensity provides a reasonable measure of acquisition of publicly-available information. In addition to professional trading platforms, Google collates information from a wide range of other sources, providing the investor with a highly diversified information set. $^{2}$ Second, individual investors have become increasingly significant as FX market participants in recent years, accounting for between $8 \%$ and 10\% of global spot FX turnover according to King and Rime, 2010. Third, and most importantly, we provide direct evidence that the trading activity of even the biggest market participants is related to SVI. For example, a unit increase in SVI is associated with an increment of about 600 trillion Yen in the trading volume of JPY/USD at weekly frequency.

By employing the SVI we are able to investigate the impact of information acquisition on FX price dynamics at the currency-specific and general market levels. ${ }^{3}$ Information acquisition has predictive power for future volatility, after controlling for the current level of volatility. We also include in our analysis an indicator of the degree of macroeconomic uncertainty, interpreted as a determinant of the need for information acquisition.

The causal association between information acquisition and currency price volatility demands further investigation. Based on a vector autoregression (VAR) model, we report empirical evidence of a causal effect running from information acquisition to volatility. This result is substantiated by including currency option price data. We find a positive association between SVI and risk aversion measured by the variance risk premium (the difference between option implied volatility and realized volatility). ${ }^{4}$ For robustness we also examine the association between the level of information acquisition and option pricing. ${ }^{5}$ We find option pricing to be associated with information acquisition, corroborating our findings on the variance risk premium. Overall our results support the notion that investor attention is a priced source of risk in FX

\footnotetext{
${ }^{2}$ Although professional investors are more likely to use professional trading platforms as sources of information such as Bloomberg or Reuters, these platforms still disseminate publicly available information only, which will be captured by Google almost instantaneously at the moment of their release.

${ }^{3}$ We thank the anonymous referee for the suggestion of studying the effects of currency-specific and general market attention jointly.

${ }^{4}$ The difference between option implied volatility and realized volatility is proposed as a measure of market risk aversion by Att-Sahalia and Lo (2000), among others.

${ }^{5}$ In estimations that are not reported in this paper we investigate the relationship between attention and traditional proxies for investors' concern over downside risk such as deep-out-of-the-money (DOTM) put options, option-implied volatility smile, and option-implied volatility skewness.
} 
markets.

Although a positive association between investor attention and uncertainty measured by volatility is intuitive, several theories suggest the opposite. For example, Freixas and Kihlstrom (1984) argue that when there is uncertainty concerning the value of information, risk averse investors are less willing to acquire information if it is costly. Huang and Liu (2007) argue that investors invest less in risky assets when they are more risk averse, reducing the benefit of more frequent information updates. Therefore information acquisition is less frequent when risk aversion is greater. Our finding of a positive association between the intensity of information acquisition and the variance risk premium is contrary to this prediction. The findings reported in this paper corroborate and extend those of Vlastakis and Markellos (2012), who find that investor attention increases with an increase in the expected variance risk premium for the S\&P 500 index.

Our results are best explained by a recent theory of investor attention and market volatility developed by Andrei and Hasler (2014). In their model, the economy has a single output process with an unobservable drift (fundamental). Investors learn about the fundamental by observing the actual output and a signal. The signal reveals more accurate information when the attention level is higher. Attention is state dependent, and related to time-varying risk aversion to extreme downturns. In bad times, investors become increasingly worried about their investments, and seek to acquire more information about fundamentals. In good times, investors have less incentive to acquire information, since they know the probability of a large downturn is low. Increased attention reveals information about the unobserved volatility of fundamentals. Market volatility is linear in filtered fundamental volatility. Under Bayesian learning, filtered volatility is higher when the signal reveals more about fundamentals. Accordingly, investor attention drives market volatility. ${ }^{6}$

To disentangle the effects of investor attention on volatility from those of macroeconomic uncertainty, news impact, liquidity risk, crash risk, investor sentiment, and differences of opinion, we include measures of these variables in our robustness checks. In addition, we examine the potential bias due to nonlinearity, outliers, and unobserved currency-specific effects. We also consider alternative lists of keywords when constructing our investor attention measures. Our main results are shown to be robust to these variations.

The remainder of the paper is organized as follows. Section 2 reviews the relevant literature. Section 3 describes and summarizes our data. Section 4 reports empirical results. Finally, Section 5 concludes.

\footnotetext{
${ }^{6}$ Andrei and Hasler (2014) show that market volatility increases quadratically due to a decline in posterior variance through learning. We do not find strong empirical support for this hypothesis.
} 


\section{Related Literature}

Given an abundance of information, investors with limited attention need to allocate their attention efficiently across different assets and over time. Recent theoretical studies examine the implications of limited attention for asset pricing. Peng (2005) shows that attention constraints lead to delayed investor reactions to fundamental shocks and predictable consumption changes. Huang and Liu (2007) develop a model of portfolio selection in the presence of rational inattention. Investors with higher risk aversion or longer investment horizons update news less frequently, but choose more accurate news updates. Peng and Xiong (2006) show that investor inattention is reflected in a tendency to focus on market- and industry-level information, rather than firm-specific information. This "category-learning" behavior, together with investor overconfidence, makes cross-sectional returns predictable. Peng et al. (2007) report empirical evidence.

Testing the empirical implications of limited attention theory requires a measure of attention. Traditional approaches rely on media coverage, extreme price movements, or advertising expenditure. These are indirect proxies that capture mainly investors' passive attention. Barber and Odean (2008) find individual investors are net buyers of attention-grabbing stocks, such as those in the news, with abnormal trading volumes, or with extreme one-day returns. According to Yuan (2011), attention-grabbing events tend to produce high selling volumes when the stock market is high, or moderate purchasing when the stock market is low. DellaVigna and Pollet (2009) report evidence that responses are less immediate, and that there is more drift for announcements on Fridays than for other weekdays. They attribute their findings to lower attention on Fridays owing to the distraction of the coming weekend. Fang and Peress (2009) show that variations in media coverage help explain cross-sectional variation in stock returns. Tetlock (2010) find patterns in post-news returns and trading volumes consistent with asymmetric information models. Engelberg and Parsons (2011) find that local media coverage predicts local trading. Fang et al. (2009) show that stocks with high media coverage are more heavily traded by mutual funds. According to Cohen and Frazzini (2008), stock prices do not incorporate news of economically linked firms, which generates a predictable subsequent price moves.

In a seminal paper, Da et al. (2011) propose a new measure of investor attention constructed from Google search intensity data. Unlike a number of previous proxies, search intensity reflects investors' active information acquisition, and hence provides a direct measure of active investor attention. The Google SVI helps predict short-term momentum and long term reversals. Subsequently, the Google SVI has been used to examine stock price adjustments to earnings announcements (Drake et al., 2011), liquidity and returns (Bank et al., 2011), prediction of firms' future cash flows (Da et al., 2010), biased attention towards local stocks (Mondria and Wu, 2012), and stock market volatility (Vlastakis and Markellos, 2012). While this literature focuses on stock markets, we examine major currency markets. 
Smith (2012) reports that SVI has incremental predictive ability beyond $\operatorname{GARCH}(1,1)$. The keywords used in his study are "crisis", "financial crisis" and "recession", which are best interpreted as sentiment measures. We examine instead the demand for information on specific currency pairs, which is not driven solely by investor sentiment. Our results are robust to the inclusion of Smith's SVI measure, which loses predictive power when our measure is also included in a GARCH regression.

This study is also related to the literature on excess volatility in foreign exchange rates. The excess volatility puzzle refers to observed volatility that is too high to be explained by movements in fundamentals according to traditional asset pricing models (Meese, 1990; Flood and Taylor, 1996). Attempts to resolve this puzzle draw on explanations such as Bayesian learning (Brennan and Xia, 2001) or adaptive learning (Adam et al., 2009) on the part of homogeneous investors, differences of opinions (Scheinkman and Xiong, 2003; Buraschi and Jiltsov, 2006), and Knightian uncertainty (Cagetti et al., 2002). Beber et al. (2010) show differences of opinions have a strong effect on implied FX volatility beyond the volatility of fundamentals. Menkhoff et al. (2012) report that global FX volatility risk explains the cross-sectional variation in carry trade returns. Unlike these papers, this study focuses on the role of investor attention in explaining variations of currency returns over time. Our results suggest that investor attention is a priced source of risk in FX markets.

We contribute to this literature by analyzing causal links between investor attention and currency price volatility, in contrast to previous studies that examine the contemporaneous relationship between attention and volatility. We fail to find empirical support for the rational inattention theory of Huang and Liu (2007).

\section{Data}

\subsection{Search Volume Index}

Google Trends provides a search volume index (SVI) computed as the ratio of worldwide Google web search on specific keywords to the total number of Google searches over a given period. These data are normalized and scaled from 0 to 100. We download weekly data from January 2004 to September 2011, providing 403 weekly observations on aggregate search volume for each of seven currency pairs: USD/JPY, GBP/USD, USD/AUD, EUR/USD, EUR/GBP, EUR/JPY and GBP/JPY. The choice of currency pairs is based on their importance and the availability of SVI data. Trading volumes for these seven pairs represents more than $69 \%$ of the total FX trading volume in $2004 .^{7}$

We consider a list of keywords for each currency pair in Google Trend. Take USD/JPY as an example, we use the following keywords "USD/JPY" + "JPY/USD" + "USD JPY" + "JPY USD" + "Dollar Yen" +

\footnotetext{
${ }^{7}$ See Triennial Central Bank Survey of Foreign Exchange and Derivatives Market Activity in 2007 at http://www.bis.org/publ/rpfxf07t.htm
} 
"Yen Dollar" + "Dollar to Yen" + "Yen to Dollar" + "Dollar/Yen" + "Yen/Dollar". 8 These keywords are unlikely to be subject to the problem of accidental increment in search volume, as in the case of SVI based on a firm's ticker or name, both of which may have multiple meanings. ${ }^{9}$ In addition to investor attention to individual currency pairs, we also consider a global investor attention measure for the FX market as a whole. For the latter we obtain the search volume index on the keywords: "FOREX" + "Foreign Exchange".

Following Vlastakis and Markellos (2012), our proxy for attention is a deseasonalized transformation of the logarithm of the raw search volume index, defined as follows:

$$
S V I_{t, k}=\log \left(S V I \_ \text {level }_{t, k}\right)-K^{-1} \sum_{s=1}^{K} \log \left(S V I \_ \text {level }{ }_{t, s}\right)
$$

where $S V I \_$level $l_{t, k}$ denotes the original search volume index for week $t$ in year $k, S V I$ denotes the deseasonalized $\log$ search volume index, and $K$ denotes the number of years. This transformation is applied to the raw market search volume index for each currency pair, and the index for the FX market as a whole. The original index and the deseasonalized log index for the FX market as a whole are denoted SVIm_level and SVIm, respectively. ${ }^{10}$ This procedure yields many missing observations for the GBP/JPY currency pair towards the start of the sample period, owing to low volumes of search activity; accordingly, many of the weekly observations are coded zero by Google.

Table 1 reports summary statistics for SVI and SVI_level for the individual currency pairs, and SVIm_level and SVIm for the FX market as a whole.

[Insert Table 1 about here]

It is important to establish whether the attention variables contain unit roots. For this purpose we conduct three unit root tests without a trend component: the Augmented Dickey-Fuller test, the Phillips-Perron test, and the DF-GLS test Elliott et al. (1996). Based on these tests we reject the presence of a unit root for SVI for every currency pair, and for the FX market as a whole.

\footnotetext{
${ }^{8}$ Google trend treats "+" as "or".

${ }^{9}$ We also consider alternative keywords based on pairs of three-letter abbreviations for currencies from ISO 4217 (Codes for the Representation of Currencies and Funds). The empirical results are similar to those reported in this paper.

${ }^{10} \mathrm{We}$ also considered an additional alternative measure of attention. This measure is constructed from the residuals of a regression of "SVI_level" on monthly dummies and its own lagged values. This procedure removes seasonality and first-order autocorrelation. We obtain similar results using this alternative attention measure.
} 


\subsection{Option Prices and FX Returns}

In the empirical analysis we use option data to explore the relationship between investors' risk aversion and investor attention. We obtain daily/weekly currency option implied volatility data from Bloomberg. The sample period is January 2004 to September 2011. The data are over-the-counter (OTC) European-style option prices provided by Bloomberg contributors. Bloomberg interpolates between the different implied volatility quotes and reports the results as market implied volatilities. The data are all denominated in US dollars. For example GBP/JPY is calculated using GBP/USD and USD/JPY, as FX rates are by convention quoted against the US dollar. We use options with one month maturity for each currency. The specific trading conventions of the FX options are described by Malz (1997).

Options data offer several informational advantages over futures or stocks. Options exist for different investment horizons, allowing the study of preferences over both specific and multiple horizons. Options provide multiple prices for different payoffs on the same underlying asset. The cross-section of options allows for forward-looking estimation of the implied volatility. Option derived distributions from a single point in time, rather than from historical time series, are more sensitive to changing market expectations.

According to the theory, if investors are rational their subjective density forecasts (risk-neutral) should on average correspond to the objective (physical) distribution from which realizations are de facto drawn. It follows that if the risk-neutral probability density function reflects market expectations, it should be an accurate predictor of the realized density function. Prediction failure due to risk aversion on the part of the representative agent drives a wedge between the subjective and objective density forecasts. We use this wedge as a candidate to explain the intensity of investors' information acquisition.

Att-Sahalia and Lo (2000) argue that the time-varying risk aversion and subjective variance estimates, known as variance risk premium (VRP), are appropriate market-level measures of risk aversion. Bollerslev et al. (2009) show that during recessions and financial crises, their time-varying risk aversion measure increases significantly. Using a particular portfolio of call options of different maturities and moneyness, Britten-Jones and Neuberger (2000) show that it is possible to derive the risk-neutral expected value of the quadratic variation of returns. Unfortunately Bloomberg does not report the data (strike prices) that would permit estimation of the quadratic variation of returns. ${ }^{11}$ Despite the advantages of "model-free" estimation documented by Jiang and Tian (2005), we are data-constrained in approximating the risk-neutral expected value of return quadratic variation from at-the-money (ATM) implied volatilities of currency options. Under

\footnotetext{
${ }^{11}$ We also estimate the currency-specific "model-free" variance risk premia from currency option prices provided by Datastream and the intra-day spot prices obtained from Bloomberg. First, we estimate the expected value of the quadratic variation of returns as in Britten-Jones and Neuberger (2000). We then estimate the excepted realized volatility (RV) based on high-frequency data as in Barndorff-Nielsen (2002) and Andersen et al. (2001). Our principal results remain unchanged when we estimate the VRP using the "model-free" method. Bollerslev et al. (2009) discuss the advantages of using "model-free" estimates of the risk-neutral and subjective variance.
} 
physical measures the quadratic variation in returns is usually estimated using squared returns. We use the exponential moving average (EMA) as an empirical proxy for the physical expected value of quadratic variation in returns. EMA is widely used by practitioners (e.g. JP Morgan's RiskMetrics, 1996).

Following Beber et al. (2010), we estimate the expected realized volatility as follows:

$$
E_{t}\left[R V_{t, T}\right]=\sqrt{\left(1-\alpha_{T-t}\right)\left(r_{t-1}^{2}+\alpha_{T-t} r_{t-2}^{2}+\alpha_{T-t}^{2} r_{t-3}^{2}+\cdots\right)}
$$

where $r_{t}$ is the log return of the underlying asset on day $t$, and $\alpha_{T-t}$ is a smoothing parameter that depends on the horizon. ${ }^{12}$

Variance Risk Premium (VRP) is obtained as the difference between the risk-neutral ATM implied volatilities $(I V)$ and the expected realized volatility in (2):

$$
V R P_{t}=I V_{t, T}-E_{t}\left[R V_{t, T}\right]
$$

Panel A of Table 2 reports summary statistics for the variance risk premium, our proxy for the representative investor's risk aversion. Panel B of Table 2 reports summary statistics for the weekly logarithmic FX returns $r_{t}^{i}=100 \times\left[\log \left(s_{t}^{i}\right)-\log \left(s_{t-1}^{i}\right)\right]$ where $s_{t}^{i}$ is the spot price for currency pair $i$ in week $t$. Most FX returns display high volatility and leptokurtosis during the sample period.

[Insert Table 2 about here]

\section{SVI and FX Investor Attention: Empirical Results}

What type of information search is captured by SVI data for FX markets? Our conjecture is that individual investors are more likely to use Google to acquire information (Da et al., 2011), while dealers acquire information through trading platforms such as Bloomberg and Reuters. Therefore SVI should reflect individual investors' demand for information. While there is evidence that the trading activities of small investors are correlated and capable of moving equity prices, ${ }^{13}$ conventional wisdom suggests that individual investors play only a limited role in dealer-dominated FX markets. However, King and Rime (2010) report that small retail investors have contributed significantly to the growth in spot currency markets, and may

\footnotetext{
${ }^{12}$ The smoothing parameter decreases with the horizon and is set at 0.1 and 0.03 for one-week and one-month horizons, respectively.

${ }^{13}$ See, for example, Kumar (2007), Barber et al. (2009a), and Barber et al. (2009b).
} 
account for $8-10 \%$ of the total trading volume. ${ }^{14}$ The rapid growth of trading by retail investors might be attributed to the spread of electronic execution methods.

\subsection{Trading Volume and Investor Attention}

We argue that Google search intensity provides a reasonable measure of the demand for information on the part of FX investors in general, if it is correlated with the trading activities of institutional investors. For example, when a dealer receives information from the trading platform, she faces a tradeoff between rapid trading, and reducing uncertainty through the acquisition of additional information from multiple sources which may include Google. Below, we report evidence that the trading activity of large institutional investors is related to SVI. Although the correlation is relatively low, it is both statistically and economically significant. We obtain weekly amounts of foreign currency holdings of large foreign exchange market participants (with more than 50 billion US Dollar foreign exchange contracts on the last business day of any calendar quarter during the previous year) from U.S. Department of the Treasury "Treasury Bulletin" reports. The "Treasury Bulletin" provides information on the amounts of foreign exchange spot contracts, foreign exchange forward contracts, foreign exchange futures contracts and one half of foreign exchange options. All these positions are reported as bought and sold. Since trading records for options contain many missing observations, we consider trading volume as the sum of buying and selling volumes for spot, forward and future contracts only. Data on trading volumes are available for three pairs of currencies: JPY/USD, GBP/USD and EUR/USD. Note that our use of trading volume data for large FX market participants is conservative. These traders are less likely than retail investors to obtain information through Google.

We examine the relationship between the weekly change in the trading volume and the change in SVI by estimating the following OLS regressions with Newey-West standard errors:

$$
\Delta \text { Volume }_{t}=\gamma_{0}+\gamma_{1} \Delta S V I_{t}+\gamma_{2} \Delta S V I_{t-1}+\gamma_{3} \Delta \text { Volume }_{t-1}+\eta_{t}
$$

Table 3 indicates that the change in trading volume is positively associated with the change in SVI at the 0.01 level for all three currency pairs. The coefficients are economically significant. For example, a one unit increase in the change of SVI is associated with an increase of 582.4 trillion Yen in the trading volume of JPY/USD.

[Insert Table 3 about here]

\footnotetext{
${ }^{14}$ The authors rely on data from the eighth Triennial Central Bank Survey of Foreign Exchange and Derivatives Market Activity ("The Triennial") of BIS. Japanese retail investors are the most active, with an estimated turnover accounting for $30 \%$ or more of spot Japanese yen trading (more than $\$ 20$ billion per day).
} 


\subsection{Volatility and Investor Attention}

We now turn to examine the relationship between FX volatility and investor attention. Figure 1(a) plots the time series of investor attention and FX market conditional volatility estimated from GARCH $(1,1)$, for one currency pair, USD/JPY. There is a positive correlation of 0.31 between SVI and the conditional volatility. We also estimate global volatility as an equally-weighted mean of the conditional volatilities for the seven currency pairs estimated from GARCH (1,1). Figure 1(b) illustrates the relationship between SVIm and the global volatility measure. The association is even stronger, with a correlation of 0.75 .

[Insert Figure 1 about here]

In order to investigate how attention affects the conditional volatility of FX returns, we augment the GARCH(1,1) model by including the investor attention measures in the conditional variance equation. We refer to this augmented model as SVI-GARCH(1,1): ${ }^{15}$

$$
\begin{aligned}
r_{t} & =\alpha+\epsilon_{t} \\
\sigma_{t}^{2} & =\exp \left(\lambda_{0}+\lambda_{1} S V I_{t}+\lambda_{2} S V I m_{t}\right)+\gamma \sigma_{t-1}^{2}+\delta \epsilon_{t-1}^{2}
\end{aligned}
$$

where $\epsilon_{t}=\sigma_{t} z_{t}$ and $z_{t} \stackrel{\text { iid }}{\sim} N(0,1)$.

Table 4 reports the estimation results for the SVI-GARCH(1,1) model. We include both the currency specific attention variable $(S V I)$ and the general FX market attention proxy (SVIm). For six of the seven currency pairs, the coefficients on currency specific attention are positive and significant in the conditional volatility equation. The relationship is significant at the 0.01 level for five currency pairs, and at the 0.05 level for GBP/JPY. EUR/GBP is the only currency pair for which attention is not significant, though attention is still positively related to the contemporaneous conditional volatility. The general FX market attention measure is positively and significantly related to contemporaneous conditional volatility for six of the seven currency pairs.

[Insert Table 4 about here]

\footnotetext{
${ }^{15} \mathrm{We}$ also employ an alternative specification of the GARCH model in which attention variables are linearly related to conditional volatility. The results confirm the positive relationship between attention and volatility.
} 
In addition to conditional volatility estimated from $\operatorname{GARCH}(1,1)$, as a robustness check, we consider two alternative volatility measures: realized volatility $(R V)$, and option-implied volatility $(I V) .{ }^{16}$ Since we do not have intra-daily data for most of our sample period, we use daily returns to calculate the weekly $R V$ :

$$
R V_{t}=\sum_{j=1}^{N} r_{t, j}^{2}
$$

where $r_{t, j}$ is the daily return for day $j$ in week $t$, and $N$ is the number of trading days in week $t$.

$I V$ is estimated using the Black-Scholes formula. We download IV directly from Bloomberg, and interpolate where necessary to construct a weekly series..

We examine the relationship between attention and each of these volatility measures by estimating the following OLS regression:

$$
\operatorname{Vola}_{t}=\lambda_{0}+\lambda_{1} \operatorname{SVI}_{t}+\lambda_{2} \operatorname{SVIm}_{t}+\lambda_{3} \operatorname{Vola}_{t-1}+\lambda_{4} \operatorname{Return}_{t}+\eta_{t}
$$

where Vola denotes either $R V$, or $I V$ as defined above, and Return denotes the weekly return for the relevant currency pair. In (8), the lagged dependent variable accounts for persistence in volatility, and the term in the contemporaneous return controls for any relationship between returns and volatility.

Panel A of Table 5 reports positive coefficients on the currency-specific attention measure in the regressions for $R V$. Four of the coefficients are significant at the 0.01 level. The coefficients for EUR/USD and USD/AUD are positive, and significant at the 0.05 and 0.10 levels, respectively. GBP/JPY is the only currency pair for which the coefficient is insignificant. The coefficients on the general FX market attention measure are positive for all seven currency pairs and statistically significant at the 0.01 level for six pairs.

Panel B reports the estimations with $I V$ as the dependent variable. The coefficients on the currency-specific attention measure are positive and significant at the 0.01 level for five of the six currency pairs. The coefficients on the general FX market attention measure are positive and significant at the 0.10 level for four of the six currency pairs.

\section{[Insert Table 5 about here]}

These results are consistent with the findings for the SVI-GARCH model. In most cases attention is positively related to contemporaneous volatility. The results are robust to the inclusion of additional lags for any of the volatility measures. Median regressions with the same specifications produce similar results.

\footnotetext{
${ }^{16}$ We thank an anonymous referee for this suggestion.
} 
Overall these results indicate a positive relationship between investor attention and volatility regardless which volatility measure is employed.

A possible concern is that volatility in fundamentals may drive both volatility in exchange rates and investor attention. We investigate this possibility using a procedure adapted from Schwert (1989). We obtain monthly series for industrial production (IP), 3-month interest rate (SR), consumer price index (CPI), unemployment rate (UE), broad money (BM) and calculate their first differences in logarithms, denoted $\Delta X_{t}$. We regress $\Delta X_{t}$ on its own first 12 lags and a set of monthly dummy variables, denoted $D_{j t}$. Denoting the absolute values of the residuals from these regressions as $\left|\hat{\varepsilon}_{t}\right|$,we estimate the following specification:

$$
\left|\hat{\varepsilon}_{t}\right|=\sum_{j=1}^{12} \gamma_{j} D_{j t}+\sum_{i=1}^{12} \rho_{i}\left|\hat{\varepsilon}_{t-i}\right|+u_{t} .
$$

The fitted values from (9), $\tilde{\varepsilon}_{t}$, are used as a proxy for the standard deviation of $\Delta X_{t}$. We include the absolute value of $\tilde{\varepsilon}_{t}$ for both countries (for each currency pair) and for each of the five series listed above as additional covariates in (8). We find that the magnitudes and significance of the coefficients on the investor attention variables are qualitatively similar to those reported in Table $5 .{ }^{17}$

\subsection{Granger Causality Tests for the Relationship between Volatility and Investor Attention}

In this section we examine the causal relationship between investor attention and volatility, using a Vector Autoregression (VAR) framework. We estimate the following VAR(2) model:

$$
\mathbf{Y}_{\mathbf{t}}=\beta_{\mathbf{0}}+\beta_{\mathbf{1}} \mathbf{Y}_{\mathbf{t}-\mathbf{1}}+\beta_{\mathbf{2}} \mathbf{Y}_{\mathbf{t}-\mathbf{2}}+\eta_{\mathbf{t}}
$$

where $\mathbf{Y}_{\mathbf{t}}=\left(\text { Vola }_{t} \text { SVI }_{t} \text { SVIm }_{t}\right)^{\prime}$

In (10), Vola denotes conditional volatility estimated from a $\mathrm{GARCH}(1,1)$ model. Table 6 reports the estimation results. ${ }^{18}$ The coefficients on the first lag of both the currency-specific attention measure and the general FX market attention measure are positive and significant in the equations for volatility for six of the seven currency pairs. On the other hand, few of the coefficients on lagged volatility are significant in the equations for the currency-specific attention and the general FX market attention measures. These results suggest that causality runs mainly from attention to volatility. Granger Causality Wald tests (not reported) support this interpretation, which is also robust to the inclusion of controls for macroeconomic uncertainty.

\footnotetext{
${ }^{17}$ The results are not reported, but are available from the corresponding author on request.

${ }^{18}$ The Bayesian information criterion (BIC) selects lag-lengths of one or two in most of the regressions. For ease of presentation, we report results based on a VAR(2) specification for all currency pairs. Our principal findings are not affected by changes in the lag length.
} 
[Insert Table 6 about here]

\subsection{Sub-sample analysis}

In this section we check for the stability of our results. For this purpose we divide the sample period into two roughly equally sized sub-periods, 2004-2007 and 2008-2011, and repeat the estimations of (8). The second sub-period includes the recent financial crisis, allowing for the possibility that the structure of the relationship between information acquisition and the dynamics of currency pricing varies with market conditions.

[Insert Table 7 about here]

Table 7 reports the estimation results for the $R V$ voilatility measure. The results for $I V$ are qualitatively similar, and are omitted. The positive relationships between both the currency-specific attention measure and the general FX market attention measure and $R V$ are stronger for the second sub-period than for the first. For the first sub-period (Panel A), the coefficients on the currency-specific attention measure are positive for six of the seven currency pairs and significant for three currency pairs. The coefficients on the general FX market attention measure are insignificant for every currency pair except EUR/USD, for which the coefficient is negative and significant. For the second sub-period (Panel B) the coefficients on the currency-specific attention measure are positive for six of the seven currency pairs, and significant at the 0.01 level for five pairs. The coefficients on the general FX market attention measure are positive and significant at the 0.01 level for all seven currency pairs. These results suggest that the structure of the relationship between investor attention and volatility is sensitive to changes in market conditions, and became stronger during the financial crisis.

\subsection{Attention and Variance Risk Premium}

In this section, we examine the association between risk aversion measured by variance risk premium $(V R P)$ and investor attention. Asset pricing theory suggests that the pricing kernel, the Arrow-Debreu state price per unit probability, forms the link between the subjective density functions used by risk averse and rational investors in forming their expectations, and the risk-neutral density function used in option pricing. ${ }^{19}$

\footnotetext{
${ }^{19}$ Under the classic assumptions of complete and frictionless markets and a single asset, Ait-Sahalia and Lo (2000) formulate the theoretical link between the risk-neutral $q\left(S_{T}\right)$ and physical $p\left(S_{T}\right)$ functions via the representative's investor utility function $U\left(S_{T}\right)$ as: $\frac{p\left(S_{T}\right)}{q\left(S_{T}\right)}=\lambda \frac{U^{\prime}\left(S_{T}\right)}{U^{\prime}\left(S_{t}\right)} \equiv \zeta\left(S_{T)}\right.$
} 
The possibility of the pricing kernel becoming disconnected from marginal rates of substitution in the real economy, even in the absence of arbitrage opportunities, is considered in the asset pricing theory of Cochrane (2001). ${ }^{20}$ It follows that if investor attention affects asset prices, this will be reflected in the slope of the volatility spread (i.e., $V R P$ ), the difference between the implied and realized volatility.

Empirically we consider the following regression, which includes lagged attention and current and lagged $V R P$.

$$
S V I_{t}=\alpha+\beta_{1} S V I_{t-1}+\beta_{2} V R P_{t}+\beta_{3} V R P_{t-1}+\varepsilon_{t}
$$

Table 8 reports the estimation results. The coefficients on $V R P_{t}$ are positive and significant for all six currency pairs. Negative and significant coefficients on $V R P_{t-1}$ are obtained for two of the six currency pairs.

These results are consistent with the notion that when the level of risk aversion increases, investors are motivated to reduce uncertainty by increasing their intensity of information acquisition. This increased effort translates into higher volatility in returns, providing the link between risk aversion and volatility in returns during times of financial distress. This channel might provide an explanation for the effects of market conditions on the relationship between the demand for information and volatility documented in Table 7.

[Insert Table 8 about here]

Our results for the relationship between SVI and VRP are relevant for testing Huang and Liu (2007) rational inattention hypothesis that information acquisition becomes less frequent when risk aversion is greater. This is because investors invest less in risky assets as the benefit of frequent information updates declines due to higher risk aversion. However, our findings on the positive relationship between information acquisition and variance risk premium are contrary to the rational inattention hypothesis.

\subsection{Robustness Check}

\subsubsection{Other Search Keywords}

So far we have considered general search keywords for each currency pair. Alternatively, we consder pairs of three-letter abbreviations as the only search keyword for each currency pair. Take USD/JPY as an example, we consider the keywords "USD/JPY" + "JPY/USD". These abbreviations are from ISO 4217 (Codes for the Representation of Currencies and Funds) and have been long used by investors and the

\footnotetext{
where $\lambda$ is constant, and $\zeta\left(S_{T}\right)$ is the pricing kernel.

${ }^{20}$ Figlewski (1989) and Green and Figlewski (1999), among others, permit sentiment to affect option prices. Stein (1989) and Poteshman (2001) show that behavioral biases affect options prices.
} 
international banking community. A search for the keyword "USD/JPY" is a clear indication of investors' interest in foreign exchange rates. The estimation results based on SVI defined using three-letter abbreviations (not reported) are qualitatively similar to those reported above.

\subsubsection{Global FX market attention and volatility}

We also examine the relationship between the global FX market attention measure and global FX market volatility, measured as the equally-weighted mean of the $\operatorname{GARCH}(1,1)$ conditional volatilities for the seven currency pairs. The estimation results (not reported) are similar to those for the individual currency pairs.

\subsubsection{Liquidity Risk}

It is widely recognized that conditional volatility may vary due to temporary changes in liquidity: high volatility is likely to correspond to low liquidity. We use the difference between the ask price and bid price as a liquidity measure, ${ }^{21}$ and examine the association between liquidity and SVI. In these estimations (not reported), all estimated coefficients on the bid-ask spread are positive, and six of the seven coefficients are significant at the 0.01 level. This indicates that attention is higher during periods of low liquidity (high bid-ask spread). During periods of high volatility, investors may require a substantial discount in order to trade, and the effort devoted to information acquisition may tend to increase. As a robustness check, median regressions are found to produce qualitatively similar results.

\subsubsection{Crash Risk}

Brunnermeier et al. (2008) report that periods of high risk of a crash in the carry trade market coincide with high market volatility measured by VIX. Investors may become more anxious when there is high risk of a crash, and hence demand more information. We examine the relationship between the risk of a crash, investor attention, and the volatility of FX returns by running VAR regressions. The risk of a crash is measured using the skewness of the daily log return over a month. The coefficient on the lagged SVI in the volatility equation is positive and significant, suggesting that SVI has predictive ability for volatility after controlling for past crash risk. There is little evidence that past crash risk drives investor attention.

\subsubsection{Impact of News}

We collect news data from the Lexis-Nexis database for the same sample period as the attention data. We examine three major newspapers: Financial Times, Wall Street Journal and New York Times. We search for all news related to "currency/exchange rates", and use the number of articles in each month as a measure of the intensity of currency market news coverage. We include this variable as an additional covariate in (8).

\footnotetext{
${ }^{21}$ The results are unaffected if we use the bid ask spread defined as $2 \times($ ask - bid $) /($ bid + ask $)$.
} 
The coefficients on the news coverage measure are insignificant for all currency pairs, and the coefficients on the investor attention measures are similar to those reported above.

\subsubsection{Investor Sentiment and Differences of Opinion}

Black (1986), De Long et al. (1990), and Foucault et al. (2011), among others, suggest that variation in investor sentiment affects volatility. Da et al. (2013) argue that internet search behavior reflects the sentiment of investors. By aggregating the volume of internet queries that are related to household concerns such as "recession" or "bankruptcy", Da et al. (2013) construct a FEAR index to measure investor sentiment, and show that increases in the FEAR index predict excess volatility. If our measure of investor attention in the FX market reflects sentiment, inclusion of the FEAR index in a regression for volatility should reduce the significance of the attention variable. When the FEAR index is included as an addiitional covariate in (8), however, the coefficients on the FEAR index are found to be insignificant, and the coefficients on the investor attention measures are similar to those reported above. In a closely related study, Smith (2012) provides evidence that SVI for keywords "crisis", "financial crisis" and "recession" has incremental predictive ability when added to a $\operatorname{GARCH}(1,1)$ conditional volatility equation. However, we find that the coefficients on an SVI measure defined in this manner are insignificant when included in a conditional volatility equation alongside our attention measure.

Finally, Beber et al. (2010) show that differences of investor opinion have a strong effect on implied FX volatility, in addition to volatility measures for fundamentals. They also examine the association between differences of opinion and volatility smile, variance risk premium and carry trade returns. We use monthly analysts forecast data on FX rates from the Centre for European Economic Research (ZEW) to build an empirical proxy for differences of opinion. The SVI investor attention measure is highly correlated with the differences of opinion measure, and our results remain robust after controlling for differences in opinion.

\section{Conclusion}

This paper reports an empirical investigation of the association between investor attention and volatility for the foreign exchange (FX) rates of seven major currency pairs, which accounted for more than $69 \%$ of the total turnover in FX markets in 2004. We examine the relationship between attention and volatility in returns, both contemporaneously and using a VAR framework, while controlling for macroeconomic uncertainty.

We report that changes in investor attention are strongly associated with changes in trading volume of the largest traders in FX markets. There is a positive and significant association between attention and volatility. Causality runs mainly from investor attention to FX market volatility, even after controlling for macroeconomic uncertainty. Investor attention is also associated with time-varying risk aversion measured by the variance risk premium. 
Our results are consistent with the notion that time-varying investor attention is a priced risk factor in FX markets. Given the (still) limited theoretical evidence, these findings suggest a need for the development of more rigorous models on the role of investor attention, in order to explain the impact on currency returns and related derivative prices. 


\section{Tables and Figures}

Figure 1. Attention and volatility

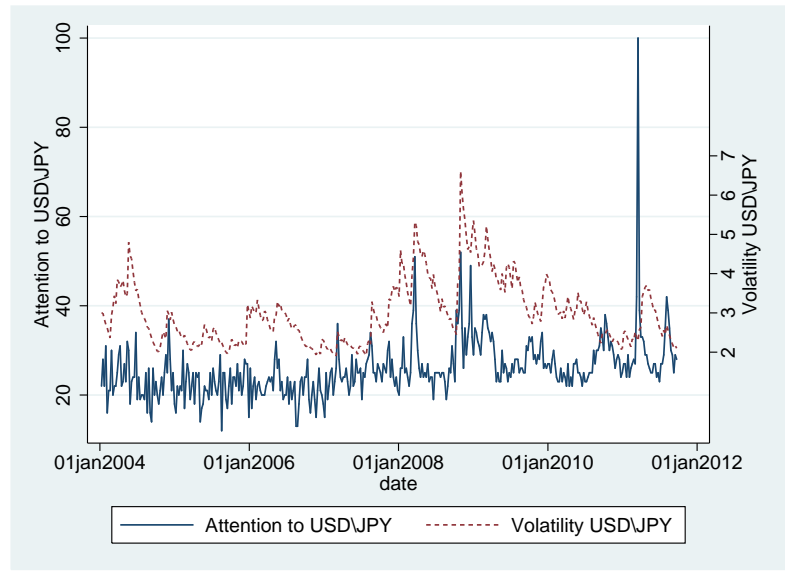

(a) USD $\backslash$ JPY Attention and Volatility

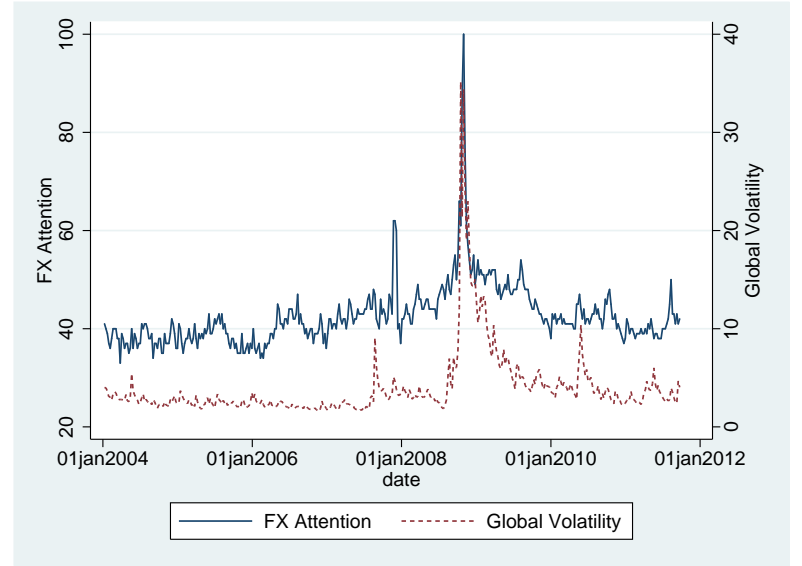

(b) FX Attention and Volatility

Panel (a) plots the weekly conditional volatility of the USD/JPY exchange rate returns and SVI, the investor attention measure for USD/JPY. SVI is obtained by using the following keywords in Google "USD/JPY" + "JPY/USD" + "USD JPY" + "JPY USD" + "Dollar Yen" + "Yen Dollar" + "Dollar to Yen" + "Yen to Dollar" + "Dollar/Yen" + "Yen/Dollar". Panel (b) plots the weekly conditional volatility of the FX market and SVIm, the global investor attention measure for foreign exchange markets. SVIm is obtained using the following keywords in Google: "FOREX" + "Foreign Exchange". Conditional volatility is estimated using a GARCH $(1,1)$ specification. Global volatility is an equally-weighted mean of the $\operatorname{GARCH}(1,1)$ conditional volatilities of the seven currency pairs. The sample period is January 2004 to September 2011. 
Table 1. Summary statistics of attention variables

This table reports summary statistics. "SVI_level" "SVIm_level" are the original Google search volume indices. "SVI" and "SVIm" are the deseasonalized log search volume indices defined by (1). The sample period is January 2004 to September 2011, and the data are weekly.

\begin{tabular}{|c|c|c|c|c|c|c|c|c|}
\hline & USD/JPY & GBP/USD & USD/AUD & EUR/USD & EUR/GBP & EUR/JPY & GBP/JPY & FX Market \\
\hline & \multicolumn{8}{|c|}{ Panel A: SVI_level and SVIm_level } \\
\hline Mean & 25.84 & 45.81 & 26.65 & 45.03 & 35.84 & 28.07 & 23.91 & 42.64 \\
\hline Std. Dev. & 6.66 & 11.79 & 14.79 & 13.63 & 12.85 & 8.89 & 21.62 & 6.46 \\
\hline Min. & 12.00 & 27.00 & 8.00 & 24.00 & 15.00 & 12.00 & 0.00 & 33.00 \\
\hline Max. & 100.00 & 100.00 & 100.00 & 100.00 & 100.00 & 100.00 & 100.00 & 100.00 \\
\hline \multirow[t]{2}{*}{ No. Observation } & 403 & 403 & 403 & 403 & 403 & 403 & 245 & 403 \\
\hline & \multicolumn{8}{|c|}{ Panel B: SVI and SVIm } \\
\hline Mean & -0.00 & 0.00 & -0.00 & -0.00 & -0.00 & -0.00 & 0.00 & -0.00 \\
\hline Std. Dev. & 0.21 & 0.23 & 0.48 & 0.30 & 0.33 & 0.28 & 0.28 & 0.12 \\
\hline Min. & -0.65 & -0.45 & -0.99 & -0.59 & -0.63 & -0.81 & -0.62 & -0.28 \\
\hline Max. & 1.19 & 0.78 & 1.26 & 0.77 & 1.00 & 1.19 & 0.80 & 0.77 \\
\hline No. Observation & 403 & 403 & 403 & 403 & 403 & 403 & 245 & 403 \\
\hline
\end{tabular}


Table 2. Summary statistics of variance risk premium and weekly FX returns

In this table, panel A reports summary statistics for the variance risk premium, the difference between option-implied volatility and expected realized volatility. Panel B reports summary statistics for the weekly returns series calculated from spot FX rates, defined as $\operatorname{Return} n_{t}=100 \times\left[\log \left(s_{t}\right)-\right.$ $\left.\log \left(s_{t-1}\right)\right]$, where $s_{t}$ is the spot rate in week $t$. Owing to missing observations in the option implied volatility data for USD/AUD, only six currency pairs are reported in Panel A. The sample period is January 2004 to September 2011, and the data are weekly.

\begin{tabular}{|c|c|c|c|c|c|c|c|}
\hline & USD/JPY & GBP/USD & USD/AUD & EUR/USD & EUR/GBP & EUR/JPY & GBP/JPY \\
\hline & \multicolumn{7}{|c|}{ Panel A: Variance risk premia } \\
\hline Mean & 0.014 & 0.013 & - & 0.013 & 0.011 & 0.015 & 0.018 \\
\hline Std. Dev. & 0.006 & 0.007 & - & 0.006 & 0.007 & 0.010 & 0.013 \\
\hline Min. & 0.004 & 0.004 & - & 0.003 & 0.003 & 0.002 & 0.004 \\
\hline \multirow[t]{2}{*}{ Max. } & 0.051 & 0.057 & - & 0.044 & 0.052 & 0.093 & 0.112 \\
\hline & \multicolumn{7}{|c|}{ Panel B: FX return } \\
\hline Mean & -0.10 & -0.02 & -0.11 & 0.03 & 0.07 & -0.09 & -0.16 \\
\hline Std. Dev. & 1.73 & 1.77 & 2.39 & 1.74 & 1.39 & 2.07 & 2.39 \\
\hline Min. & -7.32 & -8.86 & -5.92 & -6.96 & -7.50 & -13.86 & -16.51 \\
\hline Max. & 5.05 & 5.68 & 19.53 & 6.70 & 5.87 & 4.83 & 7.77 \\
\hline Skewness & -0.32 & -0.66 & 1.81 & -0.24 & -0.24 & -1.33 & -1.29 \\
\hline Kurtosis & 3.55 & 5.71 & 14.36 & 4.40 & 7.29 & 9.16 & 9.82 \\
\hline
\end{tabular}


Table 3. Regressions of currency trading volume on attention

This table reports estimations of (4). $\Delta$ Volume is the weekly change in currency trading volume of large foreign exchange market participants. "Treasury Bulletin" reports of the US Department of the Treasury provide weekly amounts of foreign currency holdings of large foreign exchange market participants. Currency holdings include foreign exchange spot, forward and futures contracts. Major market participants are defined as those market players that have more than 50 billion US Dollar foreign exchange contracts on the last business day of any calendar quarter during the previous year. Trading volume is calculated as the sum of buying and selling volumes for spot, forward and future contracts. SVI is the investor attention measure for each currency pair. The investor attention measure is defined in (1). Newey-West standard errors are in parenthesis. The sample period is January 2004 to September 2011, and the data are weekly. $* * *$ denotes coefficient significantly different from zero, 0.01 level; $* *$ 0.05 level; $* 0.10$ level.

\begin{tabular}{l|ccc}
\hline \hline & USD/JPY & GBP/USD & EUR/USD \\
\hline$\Delta S V I_{t}$ & $582.375^{* * *}$ & $2738.853^{* * *}$ & $14191.811^{* * *}$ \\
& $(181.622)$ & $(729.313)$ & $(3433.873)$ \\
$\Delta S V I_{t-1}$ & 249.051 & $1776.445^{* *}$ & $6644.690^{*}$ \\
& $(180.749)$ & $(762.745)$ & $(3751.450)$ \\
$\Delta$ Volume $_{t-1}$ & $-0.314^{* * *}$ & $-0.311^{* * *}$ & $-0.370^{* * *}$ \\
& $(0.055)$ & $(0.056)$ & $(0.068)$ \\
Constant & 1195.183 & 6163.554 & $26016.328^{*}$ \\
& $(1368.112)$ & $(4372.722)$ & $(14944.484)$ \\
Adj. R-squared & 0.11 & 0.12 & 0.16 \\
$\mathrm{~N}$ & 402 & 402 & 402 \\
\hline \hline
\end{tabular}


Table 4. Contemporaneous volatility and attention

This table reports estimations of the SVI-GARCH(1,1) model, (5) and (6). SVI is the investor attention measure for each currency pair. SVIm is the global investor attention measure for the FX market. The investor attention measures are defined in (1). $\epsilon^{2}$ and $\sigma^{2}$ are ARCH and GARCH terms, respectively. Newey-West standard errors are in parenthesis. The sample period is January 2004 to September 2011, and the data are weekly. $* * *$ denotes coefficient significantly different from zero, 0.01 level; $* * 0.05$ level; $* 0.10$ level.

\begin{tabular}{l|ccccccc}
\hline \hline & USD/JPY & GBP/USD & USD/AUD & EUR/USD & EUR/GBP & EUR/JPY & GBP/JPY \\
\hline Mean Equation & & & & & & \\
Constant & -0.064 & 0.059 & $-0.252 * * *$ & 0.132 & 0.045 & 0.044 & $-0.248^{*}$ \\
& $(0.083)$ & $(0.071)$ & $(0.093)$ & $(0.080)$ & $(0.053)$ & $(0.089)$ & $(0.143)$ \\
Variance Equation & & & & & & & \\
$S V I_{t}$ & $1.075 * * *$ & $2.010^{* * *}$ & $1.686^{* * *}$ & $2.458^{* * *}$ & 1.181 & $2.103 * * *$ & $1.081 * *$ \\
& $(0.359)$ & $(0.438)$ & $(0.327)$ & $(0.797)$ & $(0.935)$ & $(0.519)$ & $(0.484)$ \\
$S V I m_{t}$ & $1.850^{* * *}$ & $2.831^{*} *$ & $2.929 * * *$ & 0.570 & $4.865^{* * *}$ & $1.595 *$ & $4.412^{* * *}$ \\
& $(0.635)$ & $(0.867)$ & $(0.718)$ & $(0.813)$ & $(1.472)$ & $(0.838)$ & $(0.999)$ \\
Constant & $1.205 * * *$ & $0.773 * * *$ & $1.367 * * *$ & $1.085 * * *$ & $-2.469 * * *$ & $1.057 * * *$ & $1.538^{* * *}$ \\
& $(0.155)$ & $(0.225)$ & $(0.208)$ & $(0.159)$ & $(0.486)$ & $(0.134)$ & $(0.248)$ \\
$\epsilon_{t-1}^{2}$ & 0.021 & -0.012 & 0.014 & $0.207 * * *$ & $0.089 * *$ & $0.160 * *$ & 0.076 \\
$\sigma_{t-1}^{2}$ & $(0.065)$ & $(0.070)$ & $(0.052)$ & $(0.072)$ & $(0.040)$ & $(0.067)$ & $(0.077)$ \\
$\mathrm{N}$ & -0.225 & 0.090 & 0.026 & $-0.279 * *$ & $0.847 * * *$ & -0.029 & 0.025 \\
\hline \hline
\end{tabular}


Table 5. Investor attention, realized and option-implied volatility

\begin{tabular}{|c|c|c|c|c|c|c|c|}
\hline & USD/JPY & GBP/USD & USD/AUD & EUR/USD & EUR/GBP & EUR/JPY & GBP/JPY \\
\hline & \multicolumn{7}{|c|}{ Panel A: Attention and Realized Volatility $(R V)$} \\
\hline & USD/JPY & GBP/USD & USD/AUD & EUR/USD & EUR/GBP & EUR/JPY & GBP/JPY \\
\hline$\overline{S V I_{t}}$ & $\begin{array}{c}2.011 * * * \\
(0.772)\end{array}$ & $\begin{array}{c}3.979 * * * \\
(0.750)\end{array}$ & $\begin{array}{l}1.043^{*} \\
(0.561)\end{array}$ & $\begin{array}{c}0.881^{* *} \\
(0.392)\end{array}$ & $\begin{array}{c}1.851 * * * \\
(0.561)\end{array}$ & $\begin{array}{c}3.939 * * * \\
(1.216)\end{array}$ & $\begin{array}{c}0.509 \\
(1.649)\end{array}$ \\
\hline$S V \operatorname{Im}_{t}$ & $\begin{array}{c}7.708 * * * \\
(1.737)\end{array}$ & $\begin{array}{c}9.671 * * * \\
(3.058)\end{array}$ & $\begin{array}{c}17.283^{* * * *} \\
(5.435)\end{array}$ & $\begin{array}{c}5.303 * * * \\
(1.897)\end{array}$ & $\begin{array}{c}3.542 * * * \\
(1.016)\end{array}$ & $\begin{array}{c}10.913 * * \\
(4.305)\end{array}$ & $\begin{array}{c}33.284 * * * \\
(8.512)\end{array}$ \\
\hline$R V_{t-1}$ & $\begin{array}{l}-0.017 \\
(0.048)\end{array}$ & $\begin{array}{c}0.049 \\
(0.089)\end{array}$ & $\begin{array}{c}0.413 * * * \\
(0.093)\end{array}$ & $\begin{array}{c}0.247 * * * \\
(0.087)\end{array}$ & $\begin{array}{c}0.239 * * \\
(0.098)\end{array}$ & $\begin{array}{c}0.152 \\
(0.097)\end{array}$ & $\begin{array}{c}0.130 \\
(0.090)\end{array}$ \\
\hline Return $_{t}$ & $\begin{array}{l}-0.212^{*} \\
(0.108)\end{array}$ & $\begin{array}{c}0.008 \\
(0.097)\end{array}$ & $\begin{array}{l}1.515^{* *} \\
(0.711)\end{array}$ & $\begin{array}{c}0.097 \\
(0.162)\end{array}$ & $\begin{array}{c}0.079 \\
(0.225)\end{array}$ & $\begin{array}{c}-0.737 * * * \\
(0.205)\end{array}$ & $\begin{array}{c}-0.709 * * * \\
(0.272)\end{array}$ \\
\hline Constant & $\begin{array}{c}2.308 * * * \\
(0.194)\end{array}$ & $\begin{array}{c}2.035 * * * \\
(0.241)\end{array}$ & $\begin{array}{c}2.821 * * * \\
(0.483)\end{array}$ & $\begin{array}{c}1.565 * * * \\
(0.192)\end{array}$ & $\begin{array}{c}1.024 * * * \\
(0.162)\end{array}$ & $\begin{array}{c}2.655^{* * *} * \\
(0.414)\end{array}$ & $\begin{array}{c}2.759 * * * \\
(0.438)\end{array}$ \\
\hline \multirow[t]{3}{*}{$\mathrm{N}$} & $\begin{array}{c}0.22 \\
402\end{array}$ & $\begin{array}{c}0.42 \\
402\end{array}$ & $\begin{array}{l}0.53 \\
402\end{array}$ & $\begin{array}{l}0.27 \\
402\end{array}$ & $\begin{array}{c}0.32 \\
402\end{array}$ & $\begin{array}{l}0.45 \\
402\end{array}$ & $\begin{array}{l}0.46 \\
245\end{array}$ \\
\hline & \multicolumn{7}{|c|}{ Panel B: Attention and Option-Implied Volatility $(I V)$} \\
\hline & USD/JPY & GBP/USD & USD/AUD & EUR/USD & EUR/GBP & EUR/JPY & GBP/JPY \\
\hline$S V I_{t}$ & $\begin{array}{c}1.189 * * * \\
(0.339)\end{array}$ & $\begin{array}{c}2.481 * * * \\
(0.483)\end{array}$ & $\begin{array}{l}- \\
-\end{array}$ & $\begin{array}{c}0.843^{* * * *} \\
(0.256)\end{array}$ & $\begin{array}{c}0.924 * * * \\
(0.292)\end{array}$ & $\begin{array}{c}1.643^{* * * *} \\
(0.456)\end{array}$ & $\begin{array}{l}-0.380 \\
(0.422)\end{array}$ \\
\hline$S V \operatorname{Im}_{t}$ & $\begin{array}{l}7.412 * * \\
(3.632)\end{array}$ & $\begin{array}{c}3.230 * * * \\
(0.978)\end{array}$ & $\begin{array}{l}- \\
-\end{array}$ & $\begin{array}{c}1.659 \\
(1.284)\end{array}$ & $\begin{array}{c}1.865 * * * \\
(0.682)\end{array}$ & $\begin{array}{l}3.305^{*} \\
(1.955)\end{array}$ & $\begin{array}{l}-0.052 \\
(1.227)\end{array}$ \\
\hline$I V_{t-1}$ & $\begin{array}{c}0.662 * * * \\
(0.102)\end{array}$ & $\begin{array}{c}0.767 * * * \\
(0.042)\end{array}$ & $\begin{array}{l}- \\
-\end{array}$ & $\begin{array}{c}0.883^{* * * *} \\
(0.026)\end{array}$ & $\begin{array}{c}0.863 * * * \\
(0.036)\end{array}$ & $\begin{array}{c}0.823 * * * \\
(0.035)\end{array}$ & $\begin{array}{c}0.933 * * * \\
(0.026)\end{array}$ \\
\hline Return $_{t}$ & $\begin{array}{c}-0.422 * * * \\
(0.128)\end{array}$ & $\begin{array}{c}-0.174 * * * \\
(0.052)\end{array}$ & $\begin{array}{l}- \\
-\end{array}$ & $\begin{array}{l}-0.056 \\
(0.070)\end{array}$ & $\begin{array}{c}0.150 * * * \\
(0.048)\end{array}$ & $\begin{array}{c}-0.507 * * * \\
(0.107)\end{array}$ & $\begin{array}{l}-0.086 \\
(0.068)\end{array}$ \\
\hline Constant & $\begin{array}{c}3.684 * * * \\
(1.142)\end{array}$ & $\begin{array}{c}2.322 * * * \\
(0.432)\end{array}$ & $\begin{array}{l}- \\
-\end{array}$ & $\begin{array}{l}1.243 * * * \\
(0.274)\end{array}$ & $\begin{array}{c}1.093 * * * \\
(0.286)\end{array}$ & $\begin{array}{c}2.118 * * * \\
(0.428)\end{array}$ & $\begin{array}{c}1.155^{* * * *} \\
(0.341)\end{array}$ \\
\hline $\begin{array}{l}\text { Adj. R-squared } \\
\mathrm{N}\end{array}$ & $\begin{array}{c}0.84 \\
402\end{array}$ & $\begin{array}{l}0.95 \\
402\end{array}$ & $\begin{array}{l}- \\
-\end{array}$ & $\begin{array}{l}0.93 \\
402\end{array}$ & $\begin{array}{l}0.95 \\
402\end{array}$ & $\begin{array}{l}0.94 \\
402\end{array}$ & $\begin{array}{c}0.88 \\
180\end{array}$ \\
\hline
\end{tabular}


Table 6. VAR regressions of volatility and the search volume index

This table reports estimations of (10). The dependent variables in the three-equation VAR(2) model are: conditional volatility, measured by fitting a GARCH(1,1) model to the FX returns series for each currency pair, and denoted Vola; the investor attention measure for each currency pair, denoted SVI; and the global investor attention measure for the FX market, denoted SVIm. The investor attention measures are defined in (1). The sample period is January 2004 to September 2011, and the data are weekly. $* * *$ denotes coefficient significantly different from zero, 0.01 level; $* * 0.05$ level; $* 0.10$ level.

\begin{tabular}{|c|c|c|c|c|c|c|c|}
\hline & USD/JPY & GBP/USD & USD/AUD & EUR/USD & EUR/GBP & EUR/JPY & GBP/JPY \\
\hline \multicolumn{8}{|l|}{ Volatility } \\
\hline Vola $_{t-1}$ & $\begin{array}{c}0.864 * * * \\
(0.049)\end{array}$ & $\begin{array}{c}0.740 \text { *** } \\
(0.050)\end{array}$ & $\begin{array}{c}0.535 * * * \\
(0.048)\end{array}$ & $\begin{array}{c}0.459 * * * \\
(0.049)\end{array}$ & $\begin{array}{c}0.854 * * * * \\
(0.050)\end{array}$ & $\begin{array}{c}0.762^{* * * *} \\
(0.048)\end{array}$ & $\begin{array}{c}0.559^{* * * *} \\
(0.063)\end{array}$ \\
\hline Vola $_{t-2}$ & $\begin{array}{c}0.041 \\
(0.047)\end{array}$ & $\begin{array}{c}0.143^{* * * *} * \\
(0.047)\end{array}$ & $\begin{array}{c}0.040 \\
(0.050)\end{array}$ & $\begin{array}{c}0.005 \\
(0.050)\end{array}$ & $\begin{array}{c}0.046 \\
(0.049)\end{array}$ & $\begin{array}{c}0.118 * * * \\
(0.045)\end{array}$ & $\begin{array}{c}0.241 * * * \\
(0.056)\end{array}$ \\
\hline$S V I_{t-1}$ & $\begin{array}{c}0.181 * * \\
(0.080)\end{array}$ & $\begin{array}{c}1.209 * * * \\
(0.314)\end{array}$ & $\begin{array}{c}6.053 * * * \\
(1.396)\end{array}$ & $\begin{array}{c}3.172 * * * \\
(1.061)\end{array}$ & $\begin{array}{c}0.739 * * * \\
(0.272)\end{array}$ & $\begin{array}{c}1.642 * * * \\
(0.555)\end{array}$ & $\begin{array}{c}0.463 \\
(1.004)\end{array}$ \\
\hline$S V I_{t-2}$ & $\begin{array}{c}-0.031 \\
(0.080)\end{array}$ & $\begin{array}{c}-0.780 * * \\
(0.313)\end{array}$ & $\begin{array}{c}-5.324 * * * \\
(1.402)\end{array}$ & $\begin{array}{c}-2.507 * * \\
(1.073)\end{array}$ & $\begin{array}{c}-0.490 * \\
(0.275)\end{array}$ & $\begin{array}{l}-0.736 \\
(0.564)\end{array}$ & $\begin{array}{l}-0.576 \\
(0.998)\end{array}$ \\
\hline$S V \operatorname{Im}_{t-1}$ & $\begin{array}{c}1.475 * * * \\
(0.242)\end{array}$ & $\begin{array}{c}2.140^{* * * *} \\
(0.621)\end{array}$ & $\begin{array}{c}23.951 \text { *** } \\
(5.768)\end{array}$ & $\begin{array}{c}8.884 * * * \\
(1.556)\end{array}$ & $\begin{array}{l}-0.003 \\
(0.656)\end{array}$ & $\begin{array}{c}11.811^{* * * *} \\
(1.403)\end{array}$ & $\begin{array}{c}28.753 * * * \\
(3.729)\end{array}$ \\
\hline$S V \operatorname{Im}_{t-2}$ & $\begin{array}{c}-1.107 * * * \\
(0.247)\end{array}$ & $\begin{array}{l}-0.187 \\
(0.644)\end{array}$ & $\begin{array}{c}-16.757 * * * \\
(5.519)\end{array}$ & $\begin{array}{c}-6.768 * * * \\
(1.564)\end{array}$ & $\begin{array}{c}0.875 \\
(0.661)\end{array}$ & $\begin{array}{c}-9.279 * * * \\
(1.449)\end{array}$ & $\begin{array}{c}-14.242 * * * \\
(4.092)\end{array}$ \\
\hline Constant & $\begin{array}{c}0.281 * * * \\
(0.063)\end{array}$ & $\begin{array}{c}0.358 * * * \\
(0.071)\end{array}$ & $\begin{array}{c}2.407 * * * \\
(0.410)\end{array}$ & $\begin{array}{c}1.669 * * * \\
(0.179)\end{array}$ & $\begin{array}{c}0.188 * * * \\
(0.051)\end{array}$ & $\begin{array}{c}0.545^{* * *} * \\
(0.129)\end{array}$ & $\begin{array}{c}0.808 * * \\
(0.321)\end{array}$ \\
\hline \multicolumn{8}{|l|}{ SVI } \\
\hline Vola $_{t-1}$ & $\begin{array}{l}-0.027 \\
(0.031)\end{array}$ & $\begin{array}{l}-0.006 \\
(0.008)\end{array}$ & $\begin{array}{l}-0.001 \\
(0.002)\end{array}$ & $\begin{array}{c}-0.009^{* * *} * \\
(0.002)\end{array}$ & $\begin{array}{l}-0.007 \\
(0.009)\end{array}$ & $\begin{array}{l}-0.006 \\
(0.004)\end{array}$ & $\begin{array}{l}-0.004 \\
(0.004)\end{array}$ \\
\hline Vola $_{t-2}$ & $\begin{array}{c}0.036 \\
(0.029)\end{array}$ & $\begin{array}{c}0.012 \\
(0.008)\end{array}$ & $\begin{array}{l}-0.001 \\
(0.002)\end{array}$ & $\begin{array}{c}0.003 \\
(0.002)\end{array}$ & $\begin{array}{c}0.006 \\
(0.009)\end{array}$ & $\begin{array}{c}0.005 \\
(0.004)\end{array}$ & $\begin{array}{c}0.008 * * \\
(0.004)\end{array}$ \\
\hline$S V I_{t-1}$ & $\begin{array}{c}0.346 * * * \\
(0.050)\end{array}$ & $\begin{array}{c}0.656 * * * \\
(0.053)\end{array}$ & $\begin{array}{c}0.583 * * * \\
(0.048)\end{array}$ & $\begin{array}{c}0.712 * * * \\
(0.052)\end{array}$ & $\begin{array}{c}0.530 * * * \\
(0.048)\end{array}$ & $\begin{array}{c}0.488 * * * \\
(0.048)\end{array}$ & $\begin{array}{c}0.366 * * * \\
(0.066)\end{array}$ \\
\hline$S V I_{t-2}$ & $\begin{array}{c}0.262 * * * \\
(0.050)\end{array}$ & $\begin{array}{c}0.206 * * * \\
(0.052)\end{array}$ & $\begin{array}{c}0.343 * * * \\
(0.048)\end{array}$ & $\begin{array}{c}0.284 * * * \\
(0.052)\end{array}$ & $\begin{array}{c}0.401 * * * \\
(0.048)\end{array}$ & $\begin{array}{c}0.356 * * * \\
(0.049)\end{array}$ & $\begin{array}{c}0.168 * * \\
(0.066)\end{array}$ \\
\hline$S V \operatorname{Im}_{t-1}$ & $\begin{array}{c}0.617 * * * \\
(0.151)\end{array}$ & $\begin{array}{l}-0.008 \\
(0.104)\end{array}$ & $\begin{array}{c}0.403^{* *} \\
(0.198)\end{array}$ & $\begin{array}{c}0.168 * * \\
(0.076)\end{array}$ & $\begin{array}{l}-0.076 \\
(0.116)\end{array}$ & $\begin{array}{c}0.363 * * * \\
(0.122)\end{array}$ & $\begin{array}{c}0.339 \\
(0.246)\end{array}$ \\
\hline$S V \operatorname{Im}_{t-2}$ & $\begin{array}{c}-0.433 * * * \\
(0.154)\end{array}$ & $\begin{array}{c}0.028 \\
(0.108)\end{array}$ & $\begin{array}{c}-0.283 \\
(0.190)\end{array}$ & $\begin{array}{c}-0.191 * * \\
(0.076)\end{array}$ & $\begin{array}{c}0.175 \\
(0.116)\end{array}$ & $\begin{array}{l}-0.116 \\
(0.126)\end{array}$ & $\begin{array}{l}-0.140 \\
(0.270)\end{array}$ \\
\hline Constant & $\begin{array}{l}-0.027 \\
(0.039)\end{array}$ & $\begin{array}{c}-0.016 \\
(0.012)\end{array}$ & $\begin{array}{c}0.016 \\
(0.014)\end{array}$ & $\begin{array}{c}0.022 * * \\
(0.009)\end{array}$ & $\begin{array}{c}0.002 \\
(0.009)\end{array}$ & $\begin{array}{c}0.005 \\
(0.011)\end{array}$ & $\begin{array}{c}-0.049 * * \\
(0.021)\end{array}$ \\
\hline SVIm & & & & & & & \\
\hline Vola $_{t-1}$ & $\begin{array}{c}0.013 \\
(0.010)\end{array}$ & $\begin{array}{l}-0.006 \\
(0.004)\end{array}$ & $\begin{array}{c}0.002^{* * * *} \\
(0.000)\end{array}$ & $\begin{array}{l}-0.002 \\
(0.002)\end{array}$ & $\begin{array}{l}-0.004 \\
(0.004)\end{array}$ & $\begin{array}{c}0.001 \\
(0.002)\end{array}$ & $\begin{array}{c}0.000 \\
(0.001)\end{array}$ \\
\hline Vola $_{t-2}$ & $\begin{array}{l}-0.013 \\
(0.010)\end{array}$ & $\begin{array}{l}0.007^{*} \\
(0.004)\end{array}$ & $\begin{array}{l}-0.001 \\
(0.000)\end{array}$ & $\begin{array}{c}0.004 * * \\
(0.002)\end{array}$ & $\begin{array}{c}0.005 \\
(0.004)\end{array}$ & $\begin{array}{l}-0.002 \\
(0.002)\end{array}$ & $\begin{array}{l}-0.000 \\
(0.001)\end{array}$ \\
\hline$S V I_{t-1}$ & $\begin{array}{l}-0.001 \\
(0.017)\end{array}$ & $\begin{array}{c}0.001 \\
(0.027)\end{array}$ & $\begin{array}{c}0.027 * * \\
(0.012)\end{array}$ & $\begin{array}{c}0.081 * * \\
(0.036)\end{array}$ & $\begin{array}{l}-0.002 \\
(0.022)\end{array}$ & $\begin{array}{l}0.035^{*} \\
(0.020)\end{array}$ & $\begin{array}{l}-0.010 \\
(0.018)\end{array}$ \\
\hline$S V I_{t-2}$ & $\begin{array}{c}0.021 \\
(0.017)\end{array}$ & $\begin{array}{c}0.002 \\
(0.027)\end{array}$ & $\begin{array}{l}-0.021^{*} \\
(0.012)\end{array}$ & $\begin{array}{l}-0.057 \\
(0.037)\end{array}$ & $\begin{array}{c}0.014 \\
(0.022)\end{array}$ & $\begin{array}{c}0.024 \\
(0.021)\end{array}$ & $\begin{array}{c}0.003 \\
(0.018)\end{array}$ \\
\hline$S V \operatorname{Im}_{t-1}$ & $\begin{array}{c}0.816 * * * \\
(0.051)\end{array}$ & $\begin{array}{c}0.825 * * * \\
(0.053)\end{array}$ & $\begin{array}{c}0.759 * * * \\
(0.051)\end{array}$ & $\begin{array}{c}0.775 * * * \\
(0.053)\end{array}$ & $\begin{array}{c}0.817 * * * \\
(0.053)\end{array}$ & $\begin{array}{c}0.769 * * * \\
(0.052)\end{array}$ & $\begin{array}{c}0.896^{* * *} * \\
(0.068)\end{array}$ \\
\hline$S V \operatorname{Im}_{t-2}$ & $\begin{array}{c}0.069 \\
(0.053)\end{array}$ & $\begin{array}{c}0.071 \\
(0.055)\end{array}$ & $\begin{array}{l}0.081^{*} \\
(0.048)\end{array}$ & $\begin{array}{c}0.083 \\
(0.053)\end{array}$ & $\begin{array}{c}0.061 \\
(0.053)\end{array}$ & $\begin{array}{c}0.049 \\
(0.053)\end{array}$ & $\begin{array}{l}-0.020 \\
(0.075)\end{array}$ \\
\hline Constant & $\begin{array}{l}-0.000 \\
(0.013)\end{array}$ & $\begin{array}{l}-0.003 \\
(0.006)\end{array}$ & $\begin{array}{c}-0.010 * * * \\
(0.004)\end{array}$ & $\begin{array}{l}-0.006 \\
(0.006)\end{array}$ & $\begin{array}{c}-0.002 \\
(0.004)\end{array}$ & $\begin{array}{c}0.002 \\
(0.005)\end{array}$ & $\begin{array}{c}0.006 \\
(0.006)\end{array}$ \\
\hline $\mathrm{N}$ & 401 & 401 & 401 & 401 & 401 & 401 & 239 \\
\hline
\end{tabular}


Table 7. Investor attention and realized volatility for sample sub-periods

\begin{tabular}{|c|c|c|c|c|c|c|c|}
\hline & USD/JPY & GBP/USD & USD/AUD & EUR/USD & EUR/GBP & EUR/JPY & GBP/JPY \\
\hline & \multicolumn{7}{|c|}{ Panel A: Frist sub-sample Jan. 2004 - Dec. 2007} \\
\hline$\overline{S V I_{t}}$ & $\begin{array}{c}2.665 * * \\
(1.262)\end{array}$ & $\begin{array}{c}2.720 * * * \\
(0.884)\end{array}$ & $\begin{array}{c}3.273 * * \\
(1.294)\end{array}$ & $\begin{array}{c}1.116 \\
(0.803)\end{array}$ & $\begin{array}{l}-0.087 \\
(0.333)\end{array}$ & $\begin{array}{c}2.489 \\
(1.787)\end{array}$ & $\begin{array}{c}1.288 \\
(1.974)\end{array}$ \\
\hline$S V \operatorname{Im}_{t}$ & $\begin{array}{c}1.168 \\
(1.853)\end{array}$ & $\begin{array}{c}0.276 \\
(0.695)\end{array}$ & $\begin{array}{l}-0.763 \\
(2.166)\end{array}$ & $\begin{array}{c}-2.698 * * * \\
(1.002)\end{array}$ & $\begin{array}{l}-0.211 \\
(0.444)\end{array}$ & $\begin{array}{c}0.386 \\
(1.539)\end{array}$ & $\begin{array}{c}4.695 \\
(4.573)\end{array}$ \\
\hline$R V_{t-1}$ & $\begin{array}{c}0.009 \\
(0.076)\end{array}$ & $\begin{array}{c}0.033 \\
(0.070)\end{array}$ & $\begin{array}{c}0.022 \\
(0.084)\end{array}$ & $\begin{array}{c}0.106 \\
(0.071)\end{array}$ & $\begin{array}{c}0.134 \\
(0.082)\end{array}$ & $\begin{array}{l}0.125^{*} \\
(0.066)\end{array}$ & $\begin{array}{c}0.070 \\
(0.070)\end{array}$ \\
\hline Return $_{t}$ & $\begin{array}{c}-0.280 \\
(0.197)\end{array}$ & $\begin{array}{c}-0.068 \\
(0.053)\end{array}$ & $\begin{array}{c}0.525 * * \\
(0.264)\end{array}$ & $\begin{array}{l}-0.099 \\
(0.079)\end{array}$ & $\begin{array}{c}0.033 \\
(0.049)\end{array}$ & $\begin{array}{l}-0.730 \\
(0.451)\end{array}$ & $\begin{array}{c}-1.461 * * \\
(0.674)\end{array}$ \\
\hline Constant & $\begin{array}{c}2.037 * * * \\
(0.428)\end{array}$ & $\begin{array}{c}1.690 * * * \\
(0.257)\end{array}$ & $\begin{array}{c}3.613 * * * \\
(0.861)\end{array}$ & $\begin{array}{c}1.389 * * * \\
(0.252)\end{array}$ & $\begin{array}{c}0.456 * * * \\
(0.128)\end{array}$ & $\begin{array}{c}2.002 * * * \\
(0.594)\end{array}$ & $\begin{array}{c}2.231 * * * \\
(0.533)\end{array}$ \\
\hline \multirow[t]{2}{*}{$\mathrm{N}$} & $\begin{array}{l}0.10 \\
207\end{array}$ & $\begin{array}{l}0.15 \\
207\end{array}$ & $\begin{array}{l}0.19 \\
207\end{array}$ & $\begin{array}{l}0.04 \\
207\end{array}$ & $\begin{array}{l}0.01 \\
207\end{array}$ & $\begin{array}{l}0.20 \\
207\end{array}$ & $\begin{array}{c}0.39 \\
50\end{array}$ \\
\hline & \multicolumn{7}{|c|}{ Panel B: Second sub-sample Jan. 2008 - Sept. 2011} \\
\hline$S V I_{t}$ & $\begin{array}{c}2.369^{*} \\
(1.345)\end{array}$ & $\begin{array}{c}4.581^{* * *} \\
(0.906)\end{array}$ & $\begin{array}{c}4.168 * * * \\
(1.433)\end{array}$ & $\begin{array}{c}5.675^{* * *} \\
(1.895)\end{array}$ & $\begin{array}{c}7.163^{* * * *} \\
(2.735)\end{array}$ & $\begin{array}{c}10.234 * * * \\
(2.000)\end{array}$ & $\begin{array}{c}-0.573 \\
(1.965)\end{array}$ \\
\hline$S V \operatorname{Im}_{t}$ & $\begin{array}{c}13.028 * * * \\
(2.324)\end{array}$ & $\begin{array}{c}20.129 * * * \\
(4.450)\end{array}$ & $\begin{array}{c}30.830 * * * \\
(6.598)\end{array}$ & $\begin{array}{c}10.270 * * * \\
(1.935)\end{array}$ & $\begin{array}{c}5.510^{* * * *} \\
(1.692)\end{array}$ & $\begin{array}{c}16.957 * * * \\
(4.747)\end{array}$ & $\begin{array}{c}40.933 * * * \\
(8.981)\end{array}$ \\
\hline$R V_{t-1}$ & $\begin{array}{c}-0.134 * * \\
(0.063)\end{array}$ & $\begin{array}{l}-0.128 \\
(0.101)\end{array}$ & $\begin{array}{c}0.337 * * * \\
(0.091)\end{array}$ & $\begin{array}{c}0.090 \\
(0.086)\end{array}$ & $\begin{array}{c}0.077 \\
(0.106)\end{array}$ & $\begin{array}{c}0.003 \\
(0.122)\end{array}$ & $\begin{array}{c}0.083 \\
(0.103)\end{array}$ \\
\hline Return $_{t}$ & $\begin{array}{l}-0.123 \\
(0.114)\end{array}$ & $\begin{array}{c}0.083 \\
(0.114)\end{array}$ & $\begin{array}{l}1.918 * * \\
(0.908)\end{array}$ & $\begin{array}{c}0.269 \\
(0.226)\end{array}$ & $\begin{array}{c}0.029 \\
(0.265)\end{array}$ & $\begin{array}{c}-0.738 * * * \\
(0.202)\end{array}$ & $\begin{array}{c}-0.599 * * \\
(0.269)\end{array}$ \\
\hline Constant & $\begin{array}{c}2.183 * * * \\
(0.252)\end{array}$ & $\begin{array}{c}1.433 * * * \\
(0.226)\end{array}$ & $\begin{array}{c}1.050 \\
(0.725)\end{array}$ & $\begin{array}{c}0.331 \\
(0.593)\end{array}$ & $\begin{array}{l}-0.488 \\
(0.658)\end{array}$ & $\begin{array}{c}1.404 * * * \\
(0.386)\end{array}$ & $\begin{array}{c}2.828 * * * \\
(0.518)\end{array}$ \\
\hline Adj. R-squared & 0.27 & 0.53 & 0.59 & 0.36 & 0.35 & 0.49 & 0.49 \\
\hline $\mathrm{N}$ & 195 & 195 & 195 & 195 & 195 & 195 & 195 \\
\hline
\end{tabular}


Table 8. Investor attention and the variance risk premium

This table reports estimations of (11). The dependent variable is $S V I$, the investor attention measure for each currency pair. The investor attention measure is defined in (1). Variance risk premium is defined as the difference between option implied volatility and the expected realized volatility, and denoted VRP. Due to missing observations for option implied volatility for USD/AUD, results are reported for six currency pairs only. Newey-West standard errors are in parenthesis. The sample period is January 2004 to September 2011, and the data are weekly. $* * *$ denotes coefficient significantly different from zero, 0.01 level; $* * 0.05$ level; $* 0.10$ level.

\begin{tabular}{l|cccccc}
\hline \hline & USD/JPY & GBP/USD & EUR/USD & EUR/GBP & EUR/JPY & GBP/JPY \\
\hline$S V I_{t-1}$ & $0.536^{* * *}$ & $0.809^{* * *}$ & $0.971^{* * *}$ & $0.863^{* * *}$ & $0.785^{* * *}$ & $0.466^{* * *}$ \\
& $(0.053)$ & $(0.031)$ & $(0.013)$ & $(0.025)$ & $(0.044)$ & $(0.058)$ \\
$V R P_{t}$ & $4.426^{* *}$ & $7.250^{* * *}$ & $3.622^{* * *}$ & $5.327^{* *}$ & $4.687^{* * *}$ & $4.089^{* * *}$ \\
& $(2.093)$ & $(1.592)$ & $(1.121)$ & $(2.521)$ & $(1.054)$ & $(1.962)$ \\
$V R P_{t-1}$ & -0.106 & $-3.786^{* *}$ & $-4.640^{* * *}$ & -1.581 & -1.392 & 0.610 \\
& $(2.187)$ & $(1.614)$ & $(1.181)$ & $(2.281)$ & $(1.285)$ & $(1.818)$ \\
Constant & $-0.059^{* *}$ & $-0.045^{* * *}$ & 0.015 & $-0.039^{* *}$ & $-0.049^{* *}$ & $-0.096^{* * *}$ \\
& $(0.025)$ & $(0.015)$ & $(0.010)$ & $(0.015)$ & $(0.019)$ & $(0.025)$ \\
Adj. R-squared & 0.35 & 0.78 & 0.93 & 0.84 & 0.75 & 0.37 \\
$\mathrm{~N}$ & 398 & 398 & 398 & 398 & 398 & 238 \\
\hline \hline
\end{tabular}




\section{References}

Adam, K., Marcet, A., Nicolini, J., 2009. Stock Market Volatility and Learning. Working Paper .

Ait-Sahalia, Y., Lo, A., 2000. Nonparametric risk management and implied risk aversion. Journal of Econometrics 94, 9-51.

Andersen, T., Bollerslev, T., Diebold, F., Ebens, H., 2001. The distribution of realized stock return volatility. Journal of Financial Economics 61, 43-76.

Andrei, D., Hasler, M., 2014. Investor attention and stock market volatility. Review of Financial Studies .

Bacchetta, P., Van Wincoop, E., 2005. Rational inattention: A solution to the forward discount puzzle. Technical Report. National Bureau of Economic Research.

Bacchetta, P., Van Wincoop, E., 2010. Infrequent portfolio decisions: A solution to the forward discount puzzle. The American Economic Review 100, 870-904.

Bank, M., Larch, M., Peter, G., 2011. Google search volume and its influence on liquidity and returns of german stocks. Financial Markets and Portfolio Management , 1-26.

Barber, B., Odean, T., 2008. All that glitters: The effect of attention and news on the buying behavior of individual and institutional investors. Review of Financial Studies 21, 785.

Barber, B., Odean, T., Zhu, N., 2009a. Do retail trades move markets? Review of Financial Studies 22, $151-186$.

Barber, B., Odean, T., Zhu, N., 2009b. Systematic noise. Journal of Financial Markets 12, 547-569.

Barndorff-Nielsen, O.E.a., 2002. Econometric analysis of realized volatility and its use in estimating stochastic volatility models. Journal of the Royal Statistical Society: Series B (Statistical Methodology) 64, 253-280.

Beber, A., Breedon, F., Buraschi, A., 2010. Differences in beliefs and currency risk premiums. Journal of Financial Economics 98, 415-438.

Black, F., 1986. Noise. Journal of Finance 41, 529-43.

Bollerslev, T., Tauchen, G., Zhou, H., 2009. Expected stock returns and variance risk premia. Review of Financial Studies 22, 4463-4492.

Brennan, M., Xia, Y., 2001. Stock price volatility and equity premium. Journal of Monetary Economics 47, 249-283. 
Britten-Jones, M., Neuberger, A., 2000. Option prices, implied price processes, and stochastic volatility. The Journal of Finance 55, 839-866.

Brunnermeier, M., Nagel, S., Pedersen, L., 2008. Carry trades and currency crashes. NBER Macroeconomics Annual 23, 313-348.

Buraschi, A., Jiltsov, A., 2006. Model uncertainty and option markets with heterogeneous beliefs. The Journal of Finance 61, 2841-2897.

Cagetti, M., Hansen, L., Sargent, T., Williams, N., 2002. Robustness and pricing with uncertain growth. Review of Financial Studies 15, 363-404.

Cochrane, J.H., 2001. Asset Pricing. Princeton University Press.

Cohen, L., Frazzini, A., 2008. Economic links and predictable returns. The Journal of Finance 63, 1977-2011.

Da, Z., Engelberg, J., Gao, P., 2010. In search of fundamentals, Working paper, University of Notre Dame and University of North Carolina at Chapel Hill .

Da, Z., Engelberg, J., Gao, P., 2011. In search of attention. Journal of Finance 66, 1461-1499.

Da, Z., Engelberg, J., Gao, P., 2013. The sum of all fears: Investor sentiment and asset prices, Working paper, University of Notre Dame and University of North Carolina at Chapel Hill .

De Long, J., Shleifer, A., Summers, L., Waldmann, R., 1990. Noise trader risk in financial markets. Journal of Political Economy 98, 703-738.

DellaVigna, S., Pollet, J., 2009. Investor inattention and friday earnings announcements. The Journal of Finance 64, 709-749.

Drake, M., Roulstone, D., Thornock, J., 2011. Investor information demand: Evidence from Google searches around earnings announcements. Journal of Accounting Research .

Elliott, G., Rothenberg, T.J., Stock, J.H., 1996. Efficient tests for an autoregressive unit root. Econometrica $64,813-36$.

Engelberg, J., Parsons, C., 2011. The causal impact of media in financial markets. The Journal of Finance 66, 67-97.

Fang, L., Peress, J., 2009. Media coverage and the cross-section of stock returns. Journal of Finance 64, 2023-2052. 
Fang, L., Peress, J., Zheng, L., 2009. Does your fund manager trade on the news? media coverage, mutual fund trading and performance. Working Papers .

Figlewski, S., 1989. Options arbitrage in imperfect markets. Journal of Finance 44, 1289-1311.

Flood, R., Taylor, M., 1996. Exchange rate economics: What's wrong with the conventional macro approach? The microstructure of foreign exchange markets , 261.

Foucault, T., Sraer, D., Thesmar, D., 2011. Individual investors and volatility. The Journal of Finance 66, 1369-1406.

Freixas, X., Kihlstrom, R., 1984. Bayesian Models in Economic Theory. North-Holland, Amsterdam. chapter Risk aversion and information demand.

Green, T.C., Figlewski, S., 1999. Market risk and model risk for a financial institution writing options. Journal of Finance 54, 1465-1499.

Huang, L., Liu, H., 2007. Rational inattention and portfolio selection. The Journal of Finance 62, 1999-2040.

Jiang, G.J., Tian, Y.S., 2005. The model-free implied volatility and its information content. The Review of Financial Studies 18, pp. 1305-1342.

King, M., Rime, D., 2010. The $\$ 4$ trillion question: what explains FX growth since the 2007 survey? BIS Quarterly Review, December .

Kumar, A., 2007. Do the diversification choices of individual investors influence stock returns? Journal of Financial Markets 10, 362-390.

Malz, A.M., 1997. Estimating the probability distribution of the future exchange rate from option prices. The Journal of Derivatives 5, 18-36.

Meese, R., 1990. Currency fluctuations in the post-bretton woods era. The Journal of Economic Perspectives 4, 117-134.

Menkhoff, L., Sarno, L., Schmeling, M., Schrimpf, A., 2012. Carry trades and global foreign exchange volatility. Journal of Finance 67, 1540-6261.

Mondria, J., Wu, T., 2012. Asymmetric attention and stock returns, Working paper, University of Toronto .

Peng, L., 2005. Learning with information capacity constraints. Journal of Financial and Quantitative Analysis 40, 307-329. 
Peng, L., Xiong, W., 2006. Investor attention, overconfidence and category learning. Journal of Financial Economics 80, 563-602.

Peng, L., Xiong, W., Bollerslev, T., 2007. Investor attention and time-varying comovements. European Financial Management 13, 394-422.

Poteshman, A.M., 2001. Underreaction, overreaction, and increasing misreaction to information in the options market. Journal of Finance 56, 851-876.

Sager, M., Taylor, M., 2006. Under the microscope: the structure of the foreign exchange market. International Journal of Finance \& Economics 11, 81-95.

Scheinkman, J., Xiong, W., 2003. Overconfidence and speculative bubbles. Journal of Political Economy $111,1183-1220$.

Schwert, G.W., 1989. Why does stock market volatility change over time? Journal of Finance 44, 1115-1153.

Smith, G., 2012. Google internet search activity and volatility prediction in the market for foreign currency. Finance Research Letters .

Stein, J., 1989. Overreactions in the options market. Journal of Finance 44, 1011-23.

Tetlock, P., 2010. Does public financial news resolve asymmetric information? Review of Financial Studies 23,3520 .

Vlastakis, N., Markellos, R., 2012. Information demand and stock market volatility. Journal of Banking \& Finance 36, 1808-1821.

Yuan, Y., 2011. Attention and trading, Working paper, The Wharton School . 